Colloquia Litteraria

UKSW

$2 / 2014$

EWA SZCZEGLACKA-PAWŁOWSKA

\title{
DLACZEGO CYPRIAN NORWID \\ PRZECIĄŁ PAMIĄTKOWY RYSUNEK Z EGIPTU \\ OD JULIUSZA SŁOWACKIEGO? \\ O PRYWATNOŚCI W CZARNYCH KWIATACH ${ }^{1}$
}

W romantyzmie życie prywatne stało się znaczącą częścią sztuki. Jest to ogólne sformułowanie, które obejmuje wielość zagadnień i problemów o charakterze estetycznym odnoszących się do epoki romantyzmu, a także do ówczesnej kultury recepcji oraz konkretnych oczekiwań odbiorców. Życie artystów, także prywatne, w coraz większym stopniu nabierało charakteru publicznego, tzn. podlegało ocenom i oczekiwaniom ze strony publiczności. Prywatność oraz intymność miały istotny wpływ na kształtowanie się konwencji literackich, a także na kierunki rozwoju liryki.

Sfera nieoficjalna zajmuje istotne miejsce w estetyce Norwida. Jest tematem m.in. Czarnych kwiatów. Zdaje się, że autor przesunął granicę prywatności oraz intymności w sztuce, obowiązującą i uznawaną w pierwszej połowie XIX wieku. Wyjaśnienia zacznę jednak od szczegółu. Adam Mickiewicz w brulionie trzeciej części Dziadów, w didaskaliach sceny więziennej, początkowo napisał:

Kurytarz, straż z karabinem stoi opodal. Kilku więźniów młodych w szlafrokach ze świecami wychodzą z cel swoich - północ².

1 Niniejszy artykuł jest zmienionym fragmentem książki Autorki pt. Romantyzm «brulionowy», Warszawa 2015.

2 Adam Mickiewicz, Dzieła, red. nacz. Zbigniew J. Nowak, Maria Prussak, Zofia Stefanowska, Czesław Zgorzelski, Warszawa 1995, t. 3: Dramaty, oprac. Zofia Stefanowska, s. 500 (Dodatek krytyczny). 
W tekście opublikowanym znajdujemy jednak słowa:

Kurytarz - straż z karabinami stoi opodal - kilku więźniów młodych ze świecami wychodzą z cel swoich - północ ${ }^{3}$.

Więźniowie pozostali zatem w strojach dziennych. Ten szczegół jest istotny ${ }^{4}$. Mickiewicz zrezygnował ze szlafroków $\mathrm{z}$ różnych zapewne powodów, także dlatego, że „szlafrok był symbolem prywatności i jako taki się z nią wiązał"5, mógł również kształtować charakterystykę i sposób odbioru wizerunków poszczególnych osób.

Norwid w Czarnych kwiatach przedstawił postaci właśnie w kontekście nieoficjalnym, także jeśli chodzi o ubiór. Jest to szczegół, ale opis wyglądu postaci ma duże znaczenie dla charakterystyki poszczególnych bohaterów, ich sytuacji zdrowotnej, psychologicznej czy duchowej. Głównym tematem Czarnych kwiatów jest poufność ostatnich, przedśmiertnych, koleżeńskich i przyjacielskich spotkań z osobami, których status był również publiczny. Sfera nieoficjalna przeniesiona $\mathrm{w}$ ramy sztuki stała się głównym tematem arcydzieła, a także istotną cechą narracji. Czarne kwiaty odnoszą się do momentów spotkań-pożegnań. Stają się czymś w rodzaju skarbnicy pamięci, zarówno indywidualnej (tzn. związanej ze wspomnieniami Norwida), jak i zbiorowej (narodowej oraz emigracyjnej) ${ }^{6}$. Utrwalają moment

\footnotetext{
3 Tamże, s. 132.

4 Dziękuję Marii Prussak za tę sugestię interpretacyjną.
}

5 Wątek ten w odniesieniu do wybranych utworów Norwida podjęła Zofia Dambek, Kariera szlafroka, czyli wokół karykatur szlachciców Norwida, w: Norwid-artysta. W 125. rocznice śmierci poety, red. Krzysztof Trybuś, Wiesław Ratajczak, Zofia Dambek, Poznań 2008, s. 104.

6 Agata Seweryn wpisała poemat prozą w tradycję wirydarzową: „Czarne kwiaty [...] można postrzegać przez pryzmat tradycji ekfrastycznej - jako galerię dziewiętnastowiecznych portretów trumiennych - są też przecież współczesną wersją wirydarza: owych «kwiatków» i «kwiatów rymów» układanych we florilegiach i hortulusach. A jednocześnie «czarne kwiaty» odsyłają nie tylko do «ostatnich rozmów z osobami, co już w niewidzialny świat odeszły, zmarłszy tu», lecz także do topiki wanitatywnej - ścinania kosą kwiatów - wyraźniej przywołanej np. w Assuncie [...]”. Agata Seweryn, Światłocienie i dysonanse. O Norwidzie i tradycji literackiej, Lublin 2013, s. 20-21. 
przejścia od pamięci indywidualnej piszącego do pamięci zbiorowej. Owo przejście dokonało się także, a może przede wszystkim, za sprawą opublikowania poematu. Ten fakt zmienia status ostatnich odwiedzin i rozmów Cypriana Norwida z Adamem Mickiewiczem, Juliuszem Słowackim, Zygmuntem Krasińskim, Stefanem Witwickim, Paulem Delaroche’em, piękną Irlandką - których treść i przebieg zostały opowiedziane, a następnie opublikowane w postaci utworu literackiego.

Z perspektywy badań nad problemem prywatności w epoce bardzo ważna okazuje się deklaracja otwierająca Czarne kwiaty. Ujawnia ona świadomość Norwida jako pisarza, że prezentowane dzieło jest „inne” od tekstów charakterystycznych dla czasów, w których żył:

...Można by ciekawe w tym względzie rzeczy tu zapisać, ale zaraz wstręt cofa pióro i przychodzi na myśl zapytanie: „czy warto!...”. Przy pojęciach albowiem współczesnych o czytelnictwie i o twórczości piśmiennej zatracone jest prawie uczucie, kiedy pisarz stara się uniknać stylu przez uszanowanie dla rzeczy opisywanej a z siebie samej zupełnej i zajmującej, kiedy zaś, przeciwnie, nie dopracowawszy formy, styl zaniedbuje... Kiedy chodzi po ziemi, okazując, jak nisko zstąpić potrafił? kiedy zaś również nisko stąpa, przeto iż wznieść się wyżej nie mógł? Te rozróżnić odcienia, tak dla pewnych osób jednoznaczące, rzadki bardzo czytelnik dziś potrafi i dlatego niebezpiecznie jest w jakąkolwiek nową drogę na cal jeden postąpić, i dlatego najbezpieczniej jest w kółko jedne i też same motiva i formy proporcjonować tylko, nic nie wznowiwszy ani dodawszy, ani na nic się nie odważywszy.

Są wszelako w księdze żywota $i$ wiedzy ustępy takie, dla których formuł stylu nie ma, i to właśnie sztuka jest niemała oddać je i zbliżyć takimi, jakimi są. Mająż one pozostać zamkniętymi osobistymi nabytkami przez obawę rubasznego krytyka, przywykłego do dwóch tylko formuł na wszelki płód wyciętych, jako obowiązujące malarzy pokojowych wycięte patrony...?

7 Cyprian Norwid, Czarne kwiaty, w: tenże: Dzieła wszystkie, red. nacz. Stefan Sawicki, t. 7: Proza, oprac. Roman Skręt, Lublin 2007, s. 43. Wyróżnienia kursywą pochodzą od autora - C.N.. 
Powyższy fragment nie jest wstępem, lecz rozpoczynającą utwór refleksją, stanowiącą integralną część utworu. Dzieło zaczyna się od wielokropka. Nie posiada konwencjonalnego początku. Norwid postawił pytanie, sformułował problem, również o randze estetycznej, czy księga „żywota i wiedzy” (nierozdzielność sformułowania) może być tematem dzieła sztuki, ponieważ - jego zdaniem - nie ma w systemie języka „formuł stylu” dla wyrażenia tego rodzaju doświadczeń egzystencjalnych. Problem dotyczy nie tyle (lub nie tylko) stosowności obyczajowej, ile rezygnacji z wyznaczników formalnych i tego (stąd wątpliwości), czy komunikat będzie czytelny. Norwid pisał o zdarzeniach z życia konkretnych osób, których status był publiczny, m.in. o spotkaniach nieoficjalnych, a jednocześnie je uniwersalizował, czynił ponadczasowymi. Na te kwestie, w nawiązaniu do początkowych partii Czarnych kwiatów, zwracała uwagę Grażyna Halkiewicz-Sojak:

[Norwid] zadeklaruje własne poszukiwanie tych nieistniejących „formuł” - sytuowanych między „książkowym klasycyzmem” a dziennikarską publicystyką. Zwróćmy jednak uwagę na inny aspekt obecny w przywołanym cytacie - niejasną księgą okazuje się „księga żywota i wiedzy”, a zatem obszar ciemności to nie jest już całość dziejów oglądana z perspektywy „wiecznego człowieka”, lecz egzystencja wpisana w rytm przemijania - życie współczesne, w którym artysta-hermeneuta szuka znaków i słów odsyłających ku transcendencji. Można w tym miejscu sformułować hipotezę, że między powrotem Norwida z Ameryki a redakcją Vade-mecum zmienił się, w porównaniu z wcześniejszą twórczością Norwida, obszar tego, co sztuka powinna rozpoznać i rozświetlić. Można by sprawdzić trafność tego spostrzeżenia, odwołując się do wymienionych utworów [chodzi o Quidam, Białe kwiaty, Czarne kwiaty], których kształt gatunkowy wyraźnie wiąże się z poszukiwaniem artystycznej formy dla tego przesuniętego obszaru „ciemności”8.

\footnotetext{
8 Grażyna Halkiewicz-Sojak, Ciemność życia i granice wyobraźni-status poety dzisiaj (o Norwidowskich wierszach napisanych w latach 1854-1861), w: Symbol w dziele Cypriana Norwida, red. Wiesław Rzońca, Warszawa 2011, s. 30. Por. Maria Cieśla-Korytowska, Od autobiografii do... w «Czarnych» $i$ «Białych kwiatach», w: Biografie romantycznych poetów, red. Zofia Trojanowiczowa, Jerzy Borowczyk, Poznań 2007.
} 
Poeta miał świadomość rangi podejmowanych decyzji artystycznych, problemy te sformułował na początku utworu, wprowadził je do materii tekstu. Pytanie o miejsce życia prywatnego (nieoficjalnego) w literaturze, o przełamanie tabu, przekroczenie pewnej granicy, ma swoje odbicie w dalszych fragmentach utworu:

Stąd to: niezawodnie snadniej dziś upowszechni się udany pamiętnik średniowieczny niż fakt spółczesny, sumienie obowiązujący, należny mu wpływ wywrze i należną zachowa powagę. Jakoż - czytelnicy podobni są w tym do osoby oddalonej od przyjaciela swego, a mającej wizerunek jego na pamiątkę, która gdy on przyjaciel z drogi wraca: „Nie przeszkadzajże mi - rzecze jemu - bowiem oto godzina jest, w której na portret patrzeć zwykłam, listy właśnie że pisać mając”9.

Norwid zestawił tradycyjne gatunki autobiograficzne, a także być może hagiograficzne („udany pamiętnik średniowieczny”), z czymś, co autobiografię (tzn. pewien wzorzec, etos) przekracza, co określić można - bardzo jednak umownie, tylko w celu dookreślenia, sprecyzowania znaczeń, jako formę liryczną. Różnica pomiędzy tradycyjnymi gatunkami a „nowymi” próbami wysłowienia jest analogiczna do tej, jaka istnieje - używając porównania poety - pomiędzy obserwacją portretu osoby a spotkaniem tejże konkretnej osoby, która wraca $\mathrm{z}$ podróży i staje $\mathrm{w}$ drzwiach. Norwid nawiązywał do tego problemu, biorąc pod uwagę współczesnego sobie czytelnika, ukształtowanego przez obowiązujące w epoce kanony literackie. W Czarnych kwiatach przeciwstawił wysiłek obcowania $\mathrm{z}$ człowiekiem łatwości obcowania $\mathrm{z}$ artefaktem.

Następny akapit Czarnych kwiatów, tzn. rozbudowany obraz o charakterze metaforycznym, staje się zrozumiały tylko jako myśl konsekwentnie rozwijana od początku epitafijnego poematu. Norwid przywołał wspomnienie zwiedzania rzymskich katakumb. Umieścił je w Czarnych kwiatach nie tylko dlatego, że wprowadza ono czytelnika do „krainy śmierci i pamięci”, ale także po to, aby wyrazić własne doświadczenie kontaktu z tymi, którzy odeszli. Ampułki

9 Cyprian Norwid, Czarne kwiaty, dz.cyt., s. 44. 
z krwią pierwszych chrześcijan, rysunki, napisy, podpisy były dla niego czytelnymi znakami, świadectwami życia i męczeństwa konkretnych osób. Jest to lektura ukrytych w podziemiach znaków, niezwykle trwałych, wiecznych wręcz w porównaniu z kruchością ludzkiego życia. Historie ludzi odczytywane w podziemiach na podstawie znaków Norwid porównał do „półek biblioteki”, gdzie spoczywają obok siebie ludzie-książki, ludzie-opowieści. To istotny skrót myślowy odnoszący się do omawianych przez Norwida koncepcji: każde istnienie zdaje się mieć swoje miejsce w tej bibliotece, którą wiele lat później Jorge Luis Borges w opowiadaniu Biblioteka Babel nazwie wszechświatem. Norwid podjął tym samym zagadnienie związane właśnie z konwencjami estetycznymi i formami literackimi. „Ogromne podziemne miasto”, miejsce spoczynku (coemerium), do którego poeta się odwołuje, jest figurą sensu dla innego wymiaru życia, tzn. dla najbardziej wewnętrznego i głębokiego jego nurtu. W tym „ogromnym podziemnym mieście” artysta pozostanie w Czarnych kwiatach, przenosząc się w różne miejsca wyznaczone przez spotkania szczególne, ostatnie, przedśmiertne.

Zamykając epitafijny poemat, Norwid powrócił do metatematu, którym otwierał utwór:

Rzeczy tu opisane „Czarnymi kwiatami” zwę, wierne są jak podpisy świadków, którzy pisać nie umiejąc, znakami krzyża niekształtnie nakreślonego podpisują się; - kiedyś!... w literaturze, którą może zobaczę innym razem... pisma takie nie będą dziwnie wyglądały dla szukających powiastek czytelników. - Są bowiem powieści i romanse, i dramy, i tragedie w świecie niepisanym i nieliterackim, o których się naszym literatom nie śniło, ale te określać - czy warto?... już?... ${ }^{10}$.

To niezwykle ważna deklaracja autorska, że Czarne kwiaty są jak podpisy świadków, którzy, nie mogąc się już wypowiedzieć, stawiali znaki krzyża (kolejne odwołanie do podziemnego Rzymu, katakumb i napisów żłobionych przez pierwszych chrześcijan na ścianach). Mając świadomość przekraczania konwencji, Norwid

10 Tamże, s. 57. 
uczynił z Czarnych kwiatów manifest estetyczny i literacki ${ }^{11}$. Poeta sparafrazował w przywołanym powyżej cytacie Szekspirowską myśl: „Są na świecie rzeczy, o których się filozofom nie śniło”. Jest to zarazem nawiązanie do wczesnych Dziadów Mickiewicza (słowa Szekspira stanowiły przecież motto do drugiej części Dziadów). Poemat Mickiewicza zainicjował romantyzm. Był swego rodzaju moralitetem egzystencjalnym na temat śmierci, innym jednak od poematu Norwida. Ta wątpliwość poety wyrażona w zacytowanym powyżej fragmencie jest znacząca, ponieważ Norwid przekracza literackość, pisze o konkretnych osobach, ujawniając fragment ich nieoficjalnego życia. Stosuje techniki obecne w rozwijającym się w drugiej połowie XIX wieku reportażu, ale wydobywając to, co dopiero w XX wieku uznawane będzie za mistrzostwo formy, tzn. synkretyzm gatunkowy, psychologizm, podmiotowość wypowiedzi.

Obecnie Czarne kwiaty mają m.in. status eseistycznego lub lirycznego poematu ${ }^{12}$, ale Norwid posłużył się innym niż ukształtowany w epoce i uznany za literacki językiem, a także inną od dotychczasowej formą (określenia czysto umowne, gdyż w praktyce lektury trudno byłoby je oddzielić). Czarne kwiaty także dzięki opowieści o „prywatności” ustanawiają nową jakość w literaturze. Można je odczytywać jako poemat, opowiadanie, esej itp., ale czy, co należy uznać za ważne, zmienia się ich charakter, gdy interpretujemy je w kontekście pierwodruku? Czarne kwiaty były opublikowane w dodatku miesięcznym do „Czasu”. Jak ten utwór odebrali ówcześni czytelnicy? O ile np. wczesne Dziady Adama Mickiewicza można uznać

11 Na projekt estetyczny w Czarnych i Białych kwiatach, lecz w innym rozumieniu, zwrócił uwagę Sławomir Rzepczyński, «Nowy budynek estetyki». Koncepcja literatury w «Czarnych» $i$ «Białych kwiatach», w: Kazimierz Cysewski, Sławomir Rzepczyński, $O$ «Czarnych kwiatach» Norwida, Słupsk 1996.

12 O elegijności wyłaniającej się z liryczności Czarnych i Białych kwiatów pisała Bernadetta Kuczera-Chachulska, Przemiany form i postaw elegijnych $w$ liryce polskiej XIX wieku, Warszawa 2002 (rozdz. „Wokół Czarnych..., Białych kwiatów i Vade-mecum. Elegijność Norwida”). Badaczka podkreślała cykliczność Czarnych, Białych kwiatów oraz Vade-mecum, wskazując m.in., że naczelną regułą rządzącą kompozycją utworów jest „zasada bukietu”. 
za początek romantycznej estetyki wyznania (łączenia autobiografii i literatury), o tyle Czarne kwiaty wyznaczają jakąś symboliczną granicę, punkt dojścia w odniesieniu do sposobów wyrażania oraz ujawniania nieoficjalności. Inicjują również ważny nurt w sztuce. Status Czarnych kwiatów w kontekście pierwodruku w czasopiśmie wydaje się jeszcze bardziej nieokreślony. Poeta bardzo szybko zdecydował się na publikację utworu, najprawdopodobniej ukończył tekst w 1856 roku i w tym też roku go ogłosił:

[...] stało się to po 4 listopada (wówczas umarł Paul Delaroche) i zapewne w tym miesiącu, skoro pdr utworu ukazał się w grudniowym zeszycie 1856 „Dodatku Miesięcznego” do krakowskiego „Czasu”, a zeszyt ten był gotów 31 grudnia tegoż roku, ponieważ - jak zawiadamiała notka Od Redakcji - „Z numerem dzisiejszym pp. Abonenci dziennika «Czas» z Dodatkiem odbiorą zeszyt grudniowy Dodatku miesięcznego [...]"13.

W Dziadów części drugiej Mickiewicza to, co filozofom się nie śniło, istniało w świecie opowieści, zatem w świecie literackim, w perypetiach bohaterów; w Czarnych kwiatach zaś to, co najbardziej niezwykłe, o czym „nasi” literaci nie śnili, kryło się w realnym świecie i w egzystencji konkretnych osób, a zatem mających dotychczas status nieliteracki, prywatny. Filozofowie w parafrazie słów Szekspira autorstwa Norwida zostali zastąpieni przez literatów, ponieważ Norwid formułował pytania dotyczące rozwoju literatury, bezpośrednich związków dzieła sztuki i egzystencji. W świetle Czarnych kwiatów dostrzec należy związki poety z epoką, która rozpoczęła się publikacją Ballad i romansów i Dziadów części drugiej. Norwidowski projekt literatury wyrastał z twórczej relacji z jej głównym nurtem:

Romantyczność jego [Norwida] była rezultatem ścierania się tych wyobrażeń, które świadomości polskiej narzuciło pokolenia

\footnotetext{
13 Roman Skręt, Czarne kwiaty. Uwagi edytorskie, w: Cyprian Norwid, Dzieła wszystkie, t. 7, dz.cyt., s. 266. Chodzi o nr 300 „Czasu” (z 31 grudnia 1856 roku).
} 
Mickiewicza, z tymi wyobrażeniami, które były kształtowane przez długie lata paryskiego życia ${ }^{14}$.

Takie stanowisko wobec inicjujących romantyzm Dziadów zajął Norwid, odnosząc się do motta z Mickiewiczowskiego utworu, którego tematem również był kontakt ze zmarłymi. Umarli mieli jednak w Dziadach status bohaterów literackich, w Czarnych kwiatach - postaci realnych znanych $\mathrm{z}$ imienia i nazwiska. Czarne kwiaty przesunęły w literaturze polskiej granicę nieoficjalności.

Zofia Stefanowska przywołała kiedyś w rozmowie fragment utworu Norwida, a konkretnie epizod zwiedzania katakumb rzymskich i odniosła go do sceny w filmie Federica Felliniego pt. Rzym, w której odkryte pod ziemią (podczas budowy linii metra) freski, pod wpływem światła, na oczach patrzących bezpowrotnie znikają. W odniesieniu do Czarnych kwiatów można by powiedzieć, że Norwid utrwalił w utworze to, co zniknęłoby bezpowrotnie, tak jak przywołane podziemne freski, a także, dzięki sztuce, szczegół i fragment istnienia konkretnej osoby wprowadził w perspektywę ogólnoludzką. Jest to nie tylko skojarzenie, poeta przywołał w Czarnych kwiatach sztukę freskową. Studiował freski jako artysta i poeta, w sposób skrótowy, choć znaczący na ten temat mówi:

...To - pamiętam, jednego razu w Rzymie z katakomb powracałem, gdzie często patrzeć lubiłem na pozostałe freski pierwo-chrześcijańskie - rzecz, o której tu napoczynać nie chcę, bo to byłaby historia bardzo długa, o każdym znaku i o każdej linii [podkr. E.S.P.] w tych rysunkach używanej - ale tyle tylko oto wspomnę, iż to ogromne podziemne miasto $\mathrm{z}$ napisami i rysunkami swymi okazało mi, jako

14 Zofia Stefanowska, Norwid - pisarz wieku kupieckiego i przemysłowego, w: Literatura. Komparatystyka. Folklor, Warszawa 1968 (przedruk: Zofia Stefanowska, Strona romantyków. Studia o Norwidzie, Lublin 1993). Kazimierz Cysewski pisał o „literaturoznawczych dywagacjach” narratora Czarnych kwiatów, a także o jego egotyzmie. Wydaje się, że to coś znacznie więcej niż dywagacje literaturoznawcze (określenie brzmiące wobec poematu, mimo wszystko, krytycznie), „charakterystyczne” dla „niemal całej twórczości Norwida”. Kazimierz Cysewski, Narrator..., w: Kazimierz Cysewski, Sławomir Rzepczyński, $O$ «Czarnych kwiatach» Norwida, dz.cyt., s. 69. 
przez całe akta dramatu tego seraficznie-krwawego nie była prawie jedna kropelka krwi wylana bez uszanowania jej i omodlenia braterskiego współwyznawców ${ }^{15}$.

Można by się zastanowić nad freskowością Czarnych kwiatów w odniesieniu do stylu narracji oraz zamierzeń poety określonych w autotematycznych rozważaniach. Norwid miał świadomość trudu całego przedsięwzięcia, oporu formy, trudności w budowie każdej linii i konstrukcji każdego znaku. Metatekstowość ma odsłonić i wytłumaczyć trud i cel powzięty przez artystę.

Zaraz po tym fragmencie, w osobnej partii tekstu rozpoczętej od wielokropka poeta odwołał się do spotkania z pierwszą osobą Witwickim. Wobec trudności wyrażania powróciła metatekstowa refleksja:

Ile razy przypominam sobie ostatnie rozmowy z osobami, co już w niewidzialny świat odeszły, zmarłszy tu, tyle razy nie wiem, jak pominąć to, co ze zbioru razem wspomnień tych samo czasem zdaje się określać, i dlatego właśnie $\mathrm{w}$ dagerotyp raczej pióro zamieniam, aby wierności nie uchybić $[\ldots]^{16}$.

Jednak ta deklaracja zmiany stylu narracji w dagerotyp ${ }^{17}$ wydaje się tylko pozorna. Wynika raczej z uświadamianych sobie trudności artystycznych, z wątpliwości. Zmiana techniki na dagerotypową (odtwarzającą, odbijającą rzeczywistość) byłaby czymś w rodzaju rezygnacji z całego zamierzenia Norwida. To wahanie poety znajduje odzwierciedlenie w tekście poprzez sformułowanie „w dagerotyp raczej pióro zamieniam”. Podjął on nie tyle wysiłek odtwarzania zdarzeń i ich uwiecznienia (ujęcie mimetyczne), ile trud ich uwiecznienia (ujęcie metafizyczne). To główna różnica między kulturą dagerotypu a przebogatą kulturą fresku. Ostatnia z wymienionych technik

\footnotetext{
15 Cyprian Norwid, Czarne kwiaty, dz.cyt., s. 44.

16 Tamże, s. 45.

17 Na temat „dagerotypowości” Czarnych kwiatów pisali m.in.: Kazimierz Cysewski i Sławomir Rzepczyński, $O$ «Czarnych kwiatach» Norwida, dz.cyt.; Adela Kuik-Kalinowska, Cypriana Norwida «Czarne kwiaty» $i$ «Białe kwiaty», Słupsk 2002.
} 
podnosi rangę tego, co nieoficjalne w materii tekstowej Czarnych kwiatów, a więc bólu, cierpienia, świadomości śmierci. W tym miejscu skomplikowanej materii narracyjnej spotykają się męczennicy z dawnych wieków i osoby, które Norwid wspomina, spotykają się w wymiarze ludzkim: życia i śmierci. Te momenty stają się źródłem prawdy, ale nie dagerotypowej, lecz tej, która została oddana $\mathrm{w}$ arcydziełach sztuki freskowej. Przemierzane przez Norwida podziemne korytarze (dosłownie i metaforycznie - w odniesieniu do sfery śmierci) pozwalają mu tworzyć, nie odtwarzać. Studia nad „każdą linią" i „każdym znakiem” malarstwa freskowego znajdują odzwierciedlenie w Czarnych kwiatach.

Fresk wywodzi się od włoskiego słowa fresco, co znaczy: „świeży”, „na świeżym, mokrym tynku”18. Norwid malował niejako jeszcze na „mokrym, świeżym tynku”, nie tylko z powodu aktualności wydarzeń związanych ze śmiercią znanych osób, ale w odniesieniu do istoty (techniki i stylu) sztuki freskowej, której cechami wyróżniającymi są: precyzja, trwałość, a jednocześnie wymóg szybkiego tworzenia:

Ten sposób malowania ściennego jest bardzo trwały; zaleta jego trwałości polega na jednoczesnym krystalizowaniu się mokrego wapna z położonymi na nim przy pomocy pędzla farbami, zarobionymi czystą wodą. $Z$ tego powodu atoli barwy muszą należeć do niezgryzalnych przez wapno, mineralnych [...] Cała praca na ścianie musi się odbywać doraźnie - tak, aby część, jaką się rozpocznie danego dnia, w tymże dniu była ukończona, przed zaschnięciem mokrego, świeżo nałożonego tynku - dlatego też kontury postaci i ubiorów zaznacza się tępym żelazem, gwoździem, aby podeschnięte brzegi odciąć, a na drugi dzień obok nich świeżą warstwę tynku nałożyć. Pod względem wirtuozostwa malarskiego ta doraźność malowania freskowego ma zaletę znaczną: malarz musi wobec konieczności ukończenia pracy natychmiast, bez poprawek, zdobywać się na wykonanie energiczne i poprawne, dające pracy wygląd wielkiej świeżości ${ }^{19}$.

\footnotetext{
18 „Fresk”, w: Wielka Encyklopedia Powszechna Ilustrowana, Warszawa 1899, t. 23, S. 257.

19 Tamże.
} 
Norwid w Czarnych kwiatach bezpośrednio odwołuje się do malarstwa freskowego, świat fresco „otwiera” przed nim podziemia „zagrobowe”, światy pośmiertne. Śmierć osoby pozwala ponownie wydobyć jednostkowość jej życia, jeszcze wyraźniej określić „kontury” osoby, rozpoznać pozostawione „ślady” (to, co przemijaniu nie podlega - jest wieczne), stąd metaliterackie refleksje Norwida, ciągle nurtujące artystę:

Tu przychodzi mi na myśl, czy poezję tę, co prawdy rylcem ścisłej sama się w żywotach zapisuje, warto jest dla cynicznego czytelnictwa dzisiejszego piórem z niepamięci wywodzić i określać... Romans jaki, fantastycznie skłamany po zażyciu indyjskiego haczysz, przyjemniejsze i pożądańsze wrażenie zrobi!!... ${ }^{20}$

Metatekstowe rozważania Norwida świadczą o tym, że autor zmagał się z materią i tematem, było to dla niego niezwykłe wyzwanie. $\mathrm{Na}$ ten aspekt artyzmu poety zwracał uwagę Michał Kuziak pisząc o „etycznym charakterze Norwidowskiej mimesis”:

Jak sądzę, jej problematyczny charakter w Czarnych kwiatach wynika $\mathrm{z}$ etycznego pytania, jak przedstawić to, co nieprzedstawialne - doświadczenie śmierci. Czarne kwiaty zdają się ukazywać imperatyw i niemożność jej reprezentacji. Pewien jest tylko ów imperatyw. Kłopot sprawia to, co przedstawiane, podmiot przedstawiający i jego tekst. Jak bowiem mówić i pisać o tajemnicy, by ją ukazać, a zarazem jej nie naruszyć, nie zastąpić owym mówieniem i pisaniem? To chyba fundamentalne pytanie wpisane w tekst Czarnych kwiatów. Pytanie etyczne, związane $\mathrm{z}$ kategorią świadectwa, które należy dać i być może, nie wolno dawać (nie warto?). Odpowiedzią staje się praca pamięci, pozwalającej nawiązać specyficzną relację ze swoim przedmiotem, relację nostalgii - związku i dystansu, wysiłku ciągłego zbliżania się do tego, co istniało, a co pozostaje nieosiągalne ${ }^{21}$.

\footnotetext{
20 Cyprian Norwid, Czarne kwiaty, dz.cyt., s. 51.

21 Michał Kuziak, Czarne kwiaty, których nie ma, w: Strona Norwida. Studia ofiarowane Profesorowi Stefanowi Sawickiemu, red. Piotr Chlebowski, Włodzimierz Toruń, Elżbieta Żwirkowska, Edyta Chlebowska, Lublin 2008, s. 281.
} 
Mimesis w sztuce fresku, w przeciwieństwie do techniki dagerotypu, ma charakter wzniosły (metafizyczny, by nie powiedzieć transcendentny), a zatem mimesis zostaje przekroczona. Krzysztof Trybuś napisał:

Norwid upomniał się nie tylko o weryzm przedstawienia, ale przede wszystkim o właściwy dla odchodzących kształt pamięci ${ }^{22}$.

Na tej płaszczyźnie również powracają postawione wyżej w cytacie pytania. Norwid boryka się z wyzwaniem - ,jak przedstawić to, co nieprzedstawialne?”, ,jak mówić i pisać o tajemnicy?”. Wydaje się, że niezwykła próba zastosowania linii i znaku charakterystycznych dla fresku pozwala takiej możliwości i takiego sposobu poszukiwać. Malarstwo freskowe, zwłaszcza sakralne, zdaje się być wyrażeniem tego, co w konkretnych kształtach i liniach istnieje, jego tematem głównym jest właśnie tajemnica (kontekst metafizyczny).

Z podjętej tu problematyki, związanej ze sferą nieoficjalną w literaturze, rodzi się jeszcze jedno natarczywe pytanie: czy Witwicki, Słowacki, Chopin, Mickiewicz, Delaroche, piękna Irlandka zgodziliby się na publikację Czarnych kwiatów? Czy Norwid pytał ich o zdanie? Czy pytał o zgodę bliskich lub rodzinę zmarłych? Raczej nie. Czy należy zadawać takie pytania, skoro powstał utwór uznawany za arcydzieło? Czy artyzm Czarnych kwiatów uchyla sens i znaczenie tego rodzaju pytań? Mówią one wiele na temat istoty Czarnych kwiatów i decyzji Norwida.

W Czarnych kwiatach znajduje się scena o niezwykłej dla podjętej problematyki wymowie. Norwid wspomniał o rysunku, który otrzymał od Juliusza Słowackiego:

Mam rysunek Juliusza, który on w Egipcie rysował z natury, bo pejzaże zwłaszcza rysował wcale dobrze, ale przeciąłem pamiątkę tę na dwie części i jedną do albomu osoby z kraju przybyłej ofiarowałem, drugą zostawując sobie - aby sprawdziły się słowa w Beniowskim napisane: „iż prawą rękawiczkę twą zawieszą w muzeum jakim,

${ }^{22}$ Por. Krzysztof Trybuś, Pamięć romantyzmu. Studia nie tylko z przeszłości, Poznań 2011, s. 66. 
a o straconą lewą będą skargi!...” - ironia bowiem taka nadobnie-bez-zjadliwa jako ironia Juliusza pośmiertnym bynajmniej wspomnieniom nie zawadza. Owszem, brzmi ona podobnie tym słowom, które Filip Macedoński przy budzeniu się powtarzać sobie kazał: „Królu! słońce już wschodzi, pomnij przez cały dzień, że śmiertelnikiem jesteś” ${ }^{23}$.

Norwid przeciął pamiątkowy rysunek z Egiptu, który otrzymał od Słowackiego, na pół, jedną część wysłał do kraju, drugą zostawił sobie. Jego decyzja ma wymiar symboliczny, odzwierciedla dylematy metatekstowe autora Czarnych kwiatów, ujawnia koncepcję pisania i przedstawiania postaci (wkroczenie w sferę prywatności, nieoficjalności), a jednocześnie dążenie do uwiecznienia tego, co kruche i przemijające (życie osoby i pamięć o niej). Norwid z rysunku zrobił dwa urywki. Stał się współtwórcą fragmentu, ale tym samym - z jednej strony - zniszczył rysunek (pamiątkę od Juliusza Słowackiego), z drugiej - uwiecznił go w dziele sztuki. Wykonał gest trochę podobny do tego, który w XX wieku wykonał Fellini.

Ciekawe, którą kartkę (pochodzącą najprawdopodobniej z [Raptularza wschodniego]) Juliusz Słowacki podarował Norwidowi, a za sprawą Czarnych kwiatów - światu? Co mogła zawierać? Jaki był wymiar daru?

\section{Summary \\ Ewa Szczeglacka-Pawłowska, Why Cyprian Norwid tore a souvenir drawing from Egypt from Juliusz Słowacki?}

The article treats of the issues of privacy and informality in Cyprian Norwid's Czarne kwiaty [Black Flowers]. The poet wrote about events from the lives of individuals whose status was public. He wrote, among others, about informal meetings, universalising their meaning. He published the piece in a monthly insert to Czas daily newspaper. A question arises whether Norwid had the right to unveil the privacy of these people. Did he ask them to let him exploit very

23 Cyprian Norwid, Czarne kwiaty, dz.cyt., s. 49-50. 
private moments from their lives? A scene from the drama, where the narrator (the author of Czarne kwiaty) cuts a souvenir drawing from Juliusz Słowacki - he sends one half to Poland and keeps the other to himself - reveals the quintessence of the piece. By cutting the drawing from Egypt Norwid made it into two pieces; at the same time he destroyed a souvenir from Słowacki and, in a certain sense, those things that were the most private in relationships with particular people. 